\title{
O desafio de ser um editor disciplinar num periódico interdisciplinar
}

\author{
The challenge of a disciplinar editor in an interdisciplinary journal
}

\section{El desafío de ser un editor disciplinario en un periódico interdisciplinario}

Cícera Henrique da Silva | cicera.henrique@icict.fiocruz.br

Fundação Oswaldo Cruz, Instituto de Comunicação e Informação Científica e Tecnológica em Saúde, Laboratório de Pesquisa em Informação Científica e Tecnológica em Saúde e Programa de Pós-Graduação em Informação e Comunicação em Saúde. Rio de Janeiro, Brasil

Palavras-chave: periódico científico; editoria; interdisciplinaridade.

Keywords: scientific journal; editor; interdisciplinarity.

Palavras clave: periódico científico; editor; interdisciplinariedad.

Lançada em 2007, a Revista Eletrônica de Comunicação, Informação e Inovação em Saúde - Reciis nasceu repleta de desafios: eletrônica, de acesso livre, interdisciplinar e bilíngue, editada por uma unidade técnica da Fundação Oswaldo Cruz - Fiocruz, recém alçada à categoria de instituto de pesquisa, o Instituto de Comunicação e Informação Científica e Tecnológica em Saúde - ICICT. Na fala de seu primeiro editor, ela foi criada para enfocar as"... várias dimensões da dinâmica da arena da saúde, dimensões relacionadas às questões da comunicação, da informação e da inovação científica e tecnológica...”

Somam-se a estes desafios aqueles clássicos para se constituir uma fonte legítima do conhecimento produzido em uma área do conhecimento: "qualidade de artigos, regularidade na publicação e facilidade de acesso"2.

Muito se tem indagado sobre o papel desempenhado pelos editores, considerado central no processo de comunicação na ciência, a quem fica designado a maior parte das decisões a respeito do conteúdo dos 
periódicos científicos, funcionando assim como um gatekeeper da ciência. Esse papel é mais difícil de desempenhar nas ciências sociais, em que as decisões e as normas são mais subjetivas. ${ }^{3}$ O que dizer então de um periódico interdisciplinar?

Dividi com a pesquisadora Maria Cristina Soares Guimarães, por pouco mais de um ano, a editoria da Reciis, quando pudemos compartilhar as "delícias e as agruras" de sermos profissionais da informação, disciplinares, na editoria de um espaço interdisciplinar, em formação. Como decidir sobre os textos que devem ser aceitos, quando se é disciplinar e se conhece a fundo somente uma das áreas de especialidade da revista? Como estabelecer limites? Como orientar o conteúdo que virá a ser reconhecido como interdisciplinar? A quem designar o papel de parecerista, que muitas vezes também é disciplinar? Estas são algumas das questões vivenciadas neste lugar de editor. Além disso, como profissional da informação, especializado em comunicação na ciência, nosso principal objeto de pesquisa é exatamente o periódico científico. Que nova feição um periódico cientifico deve tomar em um campo emergente, à luz das Tecnologias de Informação e Comunicação - TICs? Por certo é imperativo considerar outras práticas e outros formatos de publicação, o que a Reciis vem tentando fazer ao longo dos anos numa contínua reinvenção.

Acompanha-se, desde então, a trajetória deste periódico que tem cumprido estes requisitos com muita garra e competência e, espera-se, que assim continue.

Outros desafios estão a caminho e já são realidade em outros periódicos: a publicação científica, que supera o tradicional formato textual e linear dos artigos, permitindo ainda, que comentários sejam feitos aos artigos, garantindo um "feedback" imediato aos cientistas, ${ }^{4}$ e mudança no processo de revisão pelos pares (non-blind peer review).

Aos editores, autores, pareceristas, leitores e equipe técnica da Reciis, parabéns! Que venham outras décadas e novos desafios.

\section{Referências}

1. Machado CJS. A arena da saúde na dinâmica do tempo presente. Revista Eletrônica de Comunicação, Informação \& Inovação em Saúde. 2007 jan. [citado em 21 set. 2017]; 1(1):5-7. Disponível em: https://www.reciis.icict.fiocruz.br/index.php/reciis/article/view/874

2. Mueller SP. O Círculo vicioso que prende os periódicos nacionais. DataGramaZero - Revista de Ciência da Informação, 1999 dez. [citado em 21 set. 2017]; (zero). Disponível em: http://repositorio.bce.unb.br/ bitstream/10482/985/1/ARTIGO CirculoVicioso.pdf

3. Miranda DB; Pereira MNF. O Periódico científico como veículo de comunicação: uma revisão de literatura. Ciência da Informação, 1996 dez. citado em 21 set. 2017]; 25(3). Disponível em: http://revista.ibict.br/ ciinf/article/view/636/640.

4. Ambinder DM; Marcondes CH.Novas experiências para apresentação, acesso e leitura de artigos científicos digitais na web.Transinformação[Internet]. 2013 [citado em 21 set. 2017]; 25(3):195-201. Disponível em: http://dx.doi.org/10.1590/S0103-37862013000300002. 